Article

\title{
Synthesis, Spectral and Solid State Characterization of a New Bioactive Hydrazine Bridged Cyclic Diphosphonium Compound
}

\author{
Milica Milenković ${ }^{1}$, Beata Warżajtis ${ }^{2}$, Urszula Rychlewska ${ }^{2}$, Dušanka Radanović ${ }^{3}$, \\ Katarina Anđelković ${ }^{1}$, Tatjana Božić ${ }^{1}$, Miroslava Vujčić ${ }^{3}$ and Dušan Sladić $^{1, *}$ \\ 1 Faculty of Chemistry, University of Belgrade, Studentski trg 12-16, 11000 Belgrade, Serbia \\ 2 Faculty of Chemistry, A. Mickiewicz University, Grunwaldzka 6, 60-780 Poznań, Poland \\ 3 Institute of Chemistry, Technology and Metallurgy, University of Belgrade, Njegoševa 12, \\ P.O. Box 815, 11000 Belgrade, Serbia \\ * Author to whom correspondence should be addressed; E-Mail: dsladic@chem.bg.ac.rs; \\ Tel.: +38111-333-66-79; Fax: +38111-263-60-61.
}

Received: 16 January 2012; in revised form: 21 February 2012 / Accepted: 28 February 2012 / Published: 2 March 2012

\begin{abstract}
The facile preparation of a racemic hydrazine bridged diphosphonium compound possessing a ring system analogous to bicyclo[3.3.2]decane is reported. Although the reaction yield is low, the structure of the compound, which possesses an eight-membered ring, two phosphonium cationic centers, a biimino bridge, molecular chirality and two fused aromatic rings locked into roughly perpendicular planes is unusual. The compound displays substantial biological activity in the brine shrimp test and cleaves plasmid DNA.
\end{abstract}

Keywords: hydrazine bridged diphosphonium compound; DNA cleavage; brine shrimp test; X-ray

\section{Introduction}

A major interest of our research group is devoted to metal complexes of polydentate dihydrazone ligands [1-5], mainly because some of these complexes display substantial cytotoxic activity [2-4]. While searching for new ligands we have focused our attention on those that combine both hard and soft donor atoms [6-11], in particular the heterofunctionalised phosphines, where the phosphorus is the soft donor, and the hard donor is either an oxygen or nitrogen atom. Complexes of $\mathrm{Pt}(\mathrm{II}), \mathrm{Pd}(\mathrm{II})$, and 
$\mathrm{Ni}$ (II) with the condensation derivative of 2-(diphenylphosphino)benzaldehyde and semioxamazide have been described in the literature as compounds possessing antibacterial and antifungal activity [12] and the $\mathrm{Pd}(\mathrm{II})$ complex of the condensation product of 2-(diphenylphosphino)benzaldehyde and ethyl hydrazinoacetate has been shown to exhibit anticancer activity [13].

Following these findings, we set out to prepare a condensation product of 2-(diphenylphosphino)benzaldehyde and malonic acid dihydrazide and its corresponding metal complexes. Since the synthesis of the desired ligand was unsuccessful at $\mathrm{pH} \sim 4$, more acidic conditions were applied. Moreover, a templated synthesis in the presence of the cadmium(II) and cobalt(II) ions was attempted. Surprisingly, in all cases a biimino bridged diphosphonium compound was obtained. In this paper, the synthesis, characterization and preliminary biological activity of this newly obtained compound are reported.

\section{Results and Discussion}

\subsection{Synthesis}

In order to synthesize the condensation product of 2-(diphenylphosphino)benzaldehyde and malonic acid dihydrazide, we have investigated the reaction of these compounds under diverse conditions. The optimum $\mathrm{pH}$ for this kind of condensation is typically about 4 [1], but our attempts to synthesize the desired compound at this $\mathrm{pH}$ were unsuccessful, and the starting materials were recovered.

Scheme 1. Mechanism of formation of 1.
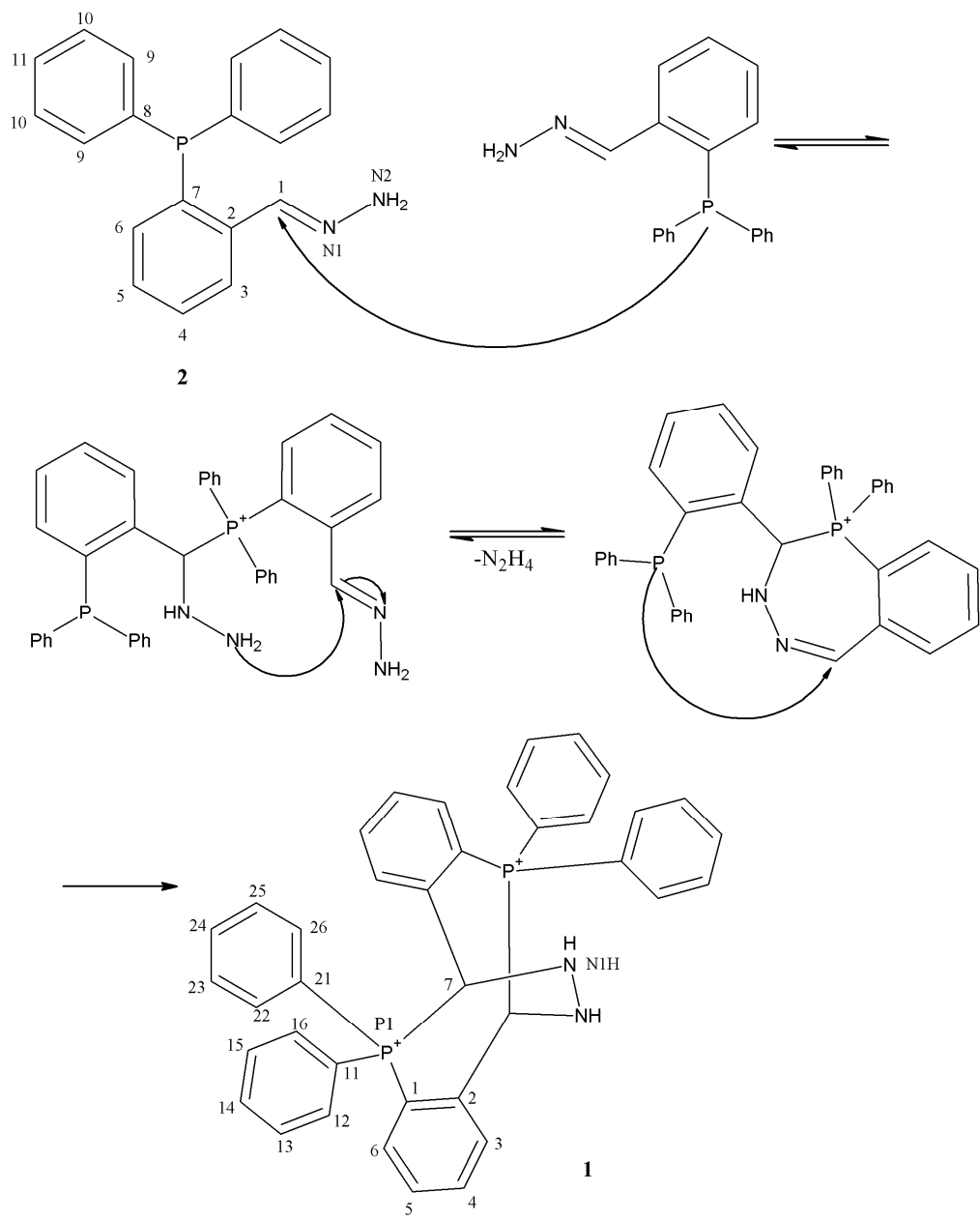
Since the presence of the electron-donating diphenylphosphino group in an aromatic aldehyde decreases the electrophilicity of the carbonyl carbon, and the electron withdrawing moiety decreases both the basicity and nucleophilicity of the nitrogen atom in malonic acid dihydrazide, the reaction of 2-(diphenylphosphino)benzaldehyde and malonic acid dihydrazide in molar ratio 2:1 was performed in methanol under more acidic conditions ( $\mathrm{pH}$ 1.5-2), affording 5,5,11,11-tetraphenyl-5,6,11,12tetrahydro-6,12-biiminodibenzo[b, $f[1,5]$ diphosphocinium diperchlorate 1 (Scheme 1) in 14.5\% yield.

In attempts to synthesize complexes of $\mathrm{Cd}$ (II) and $\mathrm{Co}$ (II) by template synthesis, starting from the corresponding perchlorate salts $\left(\mathrm{Cd}\left(\mathrm{ClO}_{4}\right)_{2} \cdot 6 \mathrm{H}_{2} \mathrm{O}\right.$ or $\left.\mathrm{Co}\left(\mathrm{ClO}_{4}\right)_{2} \cdot 6 \mathrm{H}_{2} \mathrm{O}\right)$, 2-(diphenylphosphino)benzaldehyde and malonic acid dihydrazide in molar ratio 2:2:1 in methanol at $\mathrm{pH} 1.5-2$, the title compound (1) was obtained as the reaction product. In the presence of $\mathrm{Co}$ (II) ions in the reaction solution, the unhydrated crystals of 1 were obtained in trace yield. When $\mathrm{Cd}(\mathrm{II})$ ions were present in the reaction solution after recrystallization from acetonitrile the hydrated crystals of 1 were obtained in $16.6 \%$ yield, meaning that cadmium had no significant influence on the reaction. The purification procedure of $\mathbf{1}$ using column chromatography on silica gel was unsuccessful, the main product which was isolated being (1E)-[2-(diphenylphosphino)benzylidene]hydrazine 2 (Scheme 1) in 19.0\% yield.

\subsection{X-ray Crystallographic Analysis}

Both the anhydrous (compound $\mathbf{1}$ ) and hydrated (compound $\mathbf{1} \times \mathbf{H}_{\mathbf{2}} \mathbf{O}$ ) crystals have been subjected to X-ray structure analysis. The results of these analyses are illustrated in Figure 1, which shows the dicationic moiety, the heteroanalogue of bicyclo[3.3.2]decane, common for both investigated crystal structures. Details of data collection and refinement and selected parameters describing the geometry of the molecular core are given in Tables S1 and S2 of the Supplementary Material.

The molecular cations of $\mathbf{1}$ formally possess two-fold symmetry and contain two stereogenic centers (C7 and its symmetry equivalent in Figure 1$)$ that are both of the same configuration ( $R$ for the cation depicted in Figure 1). Hence, the molecules are chiral, but their crystals, being centrosymmetric, are not. Moreover, the molecular cation of $\mathbf{1} \times \mathbf{H}_{\mathbf{2}} \mathbf{O}$ (shown in Figure 1) has an exact $C_{2}$ symmetry in the solid state while that of $\mathbf{1}$ has only an approximate $C_{2}$ symmetry (Figure S1, Supplementary Material). The conformation of the cation is nearly the same in the hydrated and the anhydrous crystals; both seven-membered rings adopt a distorted twist-chair conformation, while the eight-membered ring conformation is a twist-boat. This conformation leads to the dihedral angles of 82.07(9) in 1 and 82.37(10) ${ }^{\circ}$ in $\mathbf{1} \times \mathbf{H}_{\mathbf{2}} \mathbf{O}$ between the benzene rings fused with the eight-membered ring. The orientation of the $\mathrm{N}-\mathrm{N}$ bridge is close to staggered, the $\mathrm{H}-\mathrm{N}-\mathrm{N}-\mathrm{H}$ torsion angles being -34 and $-31^{\circ}$, in $\mathbf{1}$ and $\mathbf{1} \times \mathbf{H}_{2} \mathbf{O}$, respectively. The P $\cdots \mathrm{P}$ distances are 3.9911(10) and 4.0136(14) $\AA$, for $\mathbf{1}$ and $\mathbf{1} \times \mathbf{H}_{\mathbf{2}} \mathbf{O}$, respectively, and the intra-ring C-P-C angles are systematically wider: $115.38(14), 113.79(14)$ for $\mathbf{1}$ and $114.38(13)^{\circ}$ for $\mathbf{1} \times \mathbf{H}_{2} \mathbf{O}$, than the remaining valence angles on phosphorous, which are in the range from $103.79(14)$ to $114.32(16)^{\circ}$, the mean value being $108.3(3.5)^{\circ}$. Undoubtedly, the ring system seeks to impose planarity, which is also reflected in the intra-ring $\mathrm{P}-\mathrm{C}^{*}-\mathrm{N}$ valence angles of 112.3(2), 113.2(2) and $112.1(2)^{\circ}$. The $\mathrm{P}-\mathrm{C}$ bond lengths (mean $\mathrm{P}-\mathrm{C}\left(\mathrm{sp}^{3}\right)$ 1.865(2) $\AA$, mean $\mathrm{P}-\mathrm{C}\left(\mathrm{sp}^{2}\right)$ 1.801(4) $\AA$ ) show little deviation from the standard values listed in International Tables for X-ray crystallography [14]. 
Figure 1. View of the diphosphonium cation present in hydrated and non-hydrated crystals of 1. Displacement ellipsoids are drawn at 30\% probability level. As the molecular cation shown in this figure occupies two-fold symmetry site, the labels indicate only its symmetry independent part.

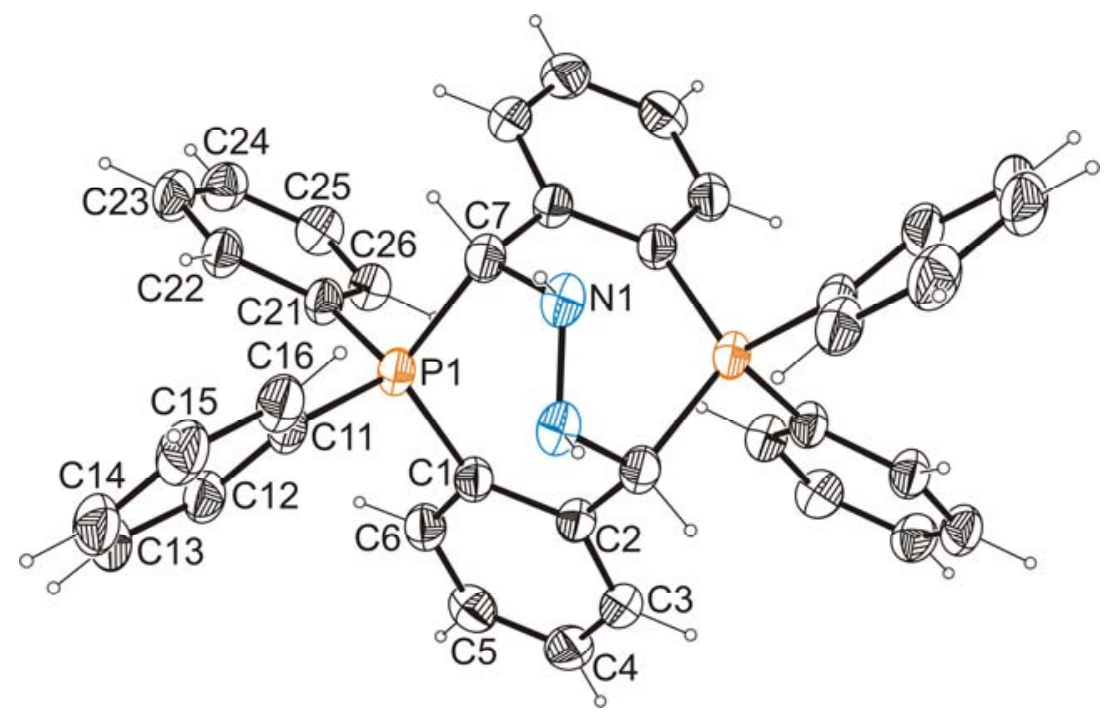

Packing in crystals is mostly governed by ionic and hydrogen-bond interactions. Hydrogen-bond parameters are listed in Table S3, and hydrogen bonding scheme is illustrated in Figures S2 and S3, Supplementary Material. In 1, the H-bonds are solely of the two-center $\mathrm{NH}^{\circ} \mathrm{O}$ type and are formed with the perchlorate groups as acceptors, while in the hydrated crystals the hydrogen bonds are also of the $\mathrm{OH} \cdots \mathrm{O}$ type. In $\mathbf{1} \times \mathbf{H}_{\mathbf{2}} \mathbf{O}$ crystals the $\mathrm{NH}$ group (and its two-fold symmetry equivalent) forms three-center hydrogen bonds by donating its protons to both the perchlorate and water oxygen atoms, and water molecule acts as a donor to the perchlorate oxygen. While in the unhydrated crystals discrete supramolecular units formed by hydrogen bonded molecules around the inversion centers are observed (Figure S2), in $\mathbf{1} \times \mathbf{H}_{2} \mathbf{O}$ addition of water molecules enables extension of hydrogen bonded molecules into tapes running along the $c$-direction and consisting of fused rings formed by hydrogen-bonded molecules around the translation related inversion centers (Figure S3).

\subsection{NMR Spectra}

The molecular cation of $\mathbf{1}$ possesses three types of NMR active nuclei: ${ }^{1} \mathrm{H},{ }^{13} \mathrm{C}$ and ${ }^{31} \mathrm{P}$. Crystals of $\mathbf{1} \times \mathbf{H}_{2} \mathbf{O}$ were dissolved in $\mathrm{CD}_{3} \mathrm{CN}$ and NMR spectra were recorded. Results obtained from 1D NMR spectra were not sufficient to resolve the structure, since signals in ${ }^{1} \mathrm{H}-\mathrm{NMR}$ spectrum are complex overlapping multiplets. Additional data were obtained from 2D NMR experiments: COSY, NOESY, HSQC and HMBC. There are no differences between the structures obtained by X-ray crystallography and NMR spectroscopy indicating the stability of $\mathbf{1}$ in $\mathrm{CD}_{3} \mathrm{CN}$ solution. Important correlations obtained from NOESY spectrum in support of this statement are shown on Figure 2. 
Figure 2. Important correlations obtained from NOESY spectrum.

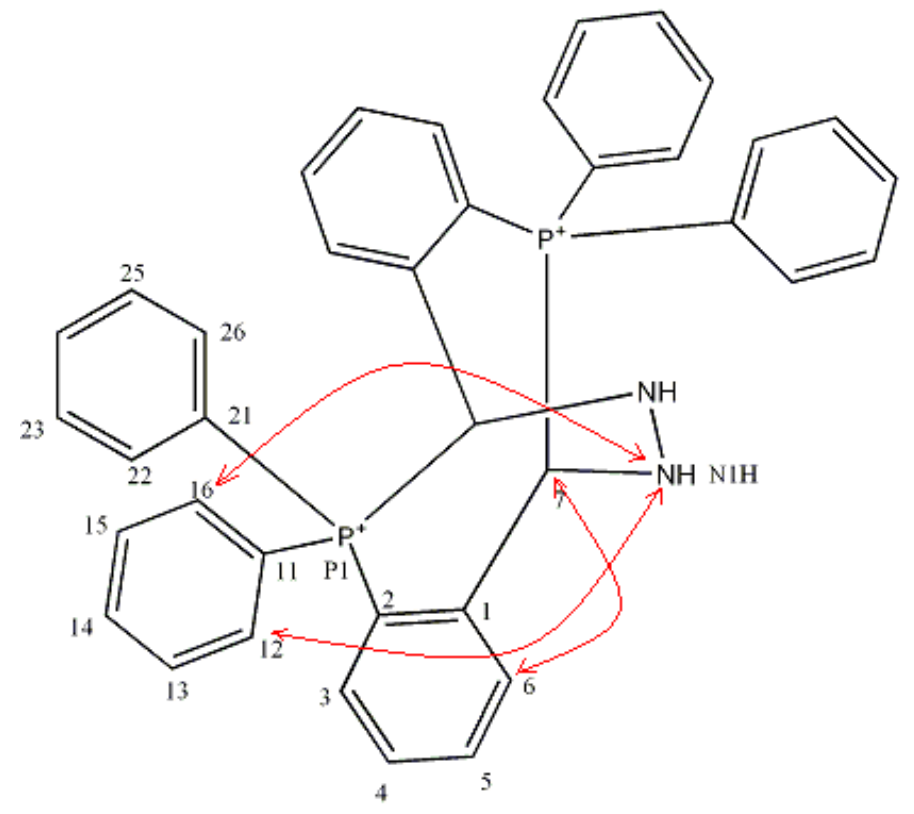

\subsection{Reaction Mechanism}

Considering the mechanism of formation of $\mathbf{1}$, we propose that malonic acid dihydrazide underwent a degradation to hydrazine under the experimental conditions, because of the coordination of the metal ion to the carbonyl oxygen lone pair due to its Lewis acidity. The metal ions of perchlorates are hard Lewis acids owing to the high delocalization of the negative charge in the perchlorate anion [15]. The liberated hydrazine reacted with 2-(diphenylphosphino)benzaldehyde, affording 1 . In order to confirm the assumption, a reaction of 2-(diphenylphosphino)benzaldehyde and hydrazine sulfate in methanol at $\mathrm{pH} 1.5-2$ in the presence of perchloric acid was performed and $\mathbf{1}$ was obtained in $18.7 \%$ yield. The probable reaction mechanism for this condensation is shown in Scheme 1. This reaction involved aldehyde and hydrazine, which form hydrazone in situ, followed by addition of nucleophilic phosphorus, cyclization, elimination of hydrazine, and addition of the second phosphorous atom to the endocyclic hydrazone moiety to afford the final product. Although the literature describiing such reactions is scarce, evidence for both the nucleophilic addition of a phosphine to the carbon-nitrogen double bond [16] and the transhydrazonation [17] exist in the literature.

There are very few structural analogues of $\mathbf{1}$. The most similar one is an eight-membered cyclic compound without a bridge, 5,6,11,12-tetrahydro-5,5,11,11-tetraphenyldibenzo[b,f][1,5]diphosphocinium dibromide, which was obtained by the intermolecular cyclization reaction of two molecules of [2-(bromomethyl)phenyl]diphenylphosphine [18].

\subsection{Biological Activity}

The biological activity of $\mathbf{1}$ and $\mathbf{2}$ was tested by the brine shrimp test (toxicity to A. salina). The results of this test can be extrapolated to cell-line toxicity and anti-tumor activity [19,20]. The brine shrimp lethality test showed a good activity for $\mathbf{1}$ with, $\mathrm{LC}_{50} 52.7 \mu \mathrm{M}$, and a moderate activity for $\mathbf{2}$ with $\mathrm{LC}_{50} 3.82 \mathrm{mM}$. 
The ability of $\mathbf{1}$ to cleave double-stranded plasmid DNA was investigated using an agarose gel electrophoresis assay. This assay allows assessment of DNA strand cleavage by measuring the conversion of uncut supercoiled (form I) plasmid DNA to the nicked form (form II) and linear form (form III). The electrophoretic separations are shown in Figure 3. Compound 1 relaxes the supercoiled plasmid DNA (form I) and nicked form (form II) to the linear form (form III) in a dose-dependent manner. Another form, with the lowest mobility, was noticed, and its amount also increased with the increase of concentration of $\mathbf{1}$. The DNA cleaving activity of $\mathbf{1}$ is probably a consequence of various structural features: its positive charge would enable it to engage in electrostatic interactions with DNA, its 8-membered macrocyclic moiety could enable groove binding to DNA, and its $\mathrm{P}, \mathrm{N}$ acetal is the reactive center which can covalently modify DNA.

Figure 3. Agarose gel electrophoresis of plasmid pUC18 DNA. pUC18 (213 ng) without (lane 1) and pUC18 (213 ng) with $5 \mathrm{nmol}, 10 \mathrm{nmol}, 15 \mathrm{nmol}, 20 \mathrm{nmol}, 25 \mathrm{nmol}$ and $30 \mathrm{nmol}$

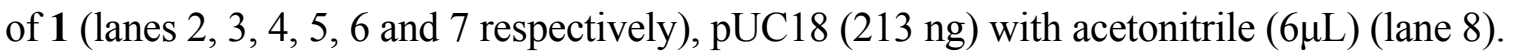

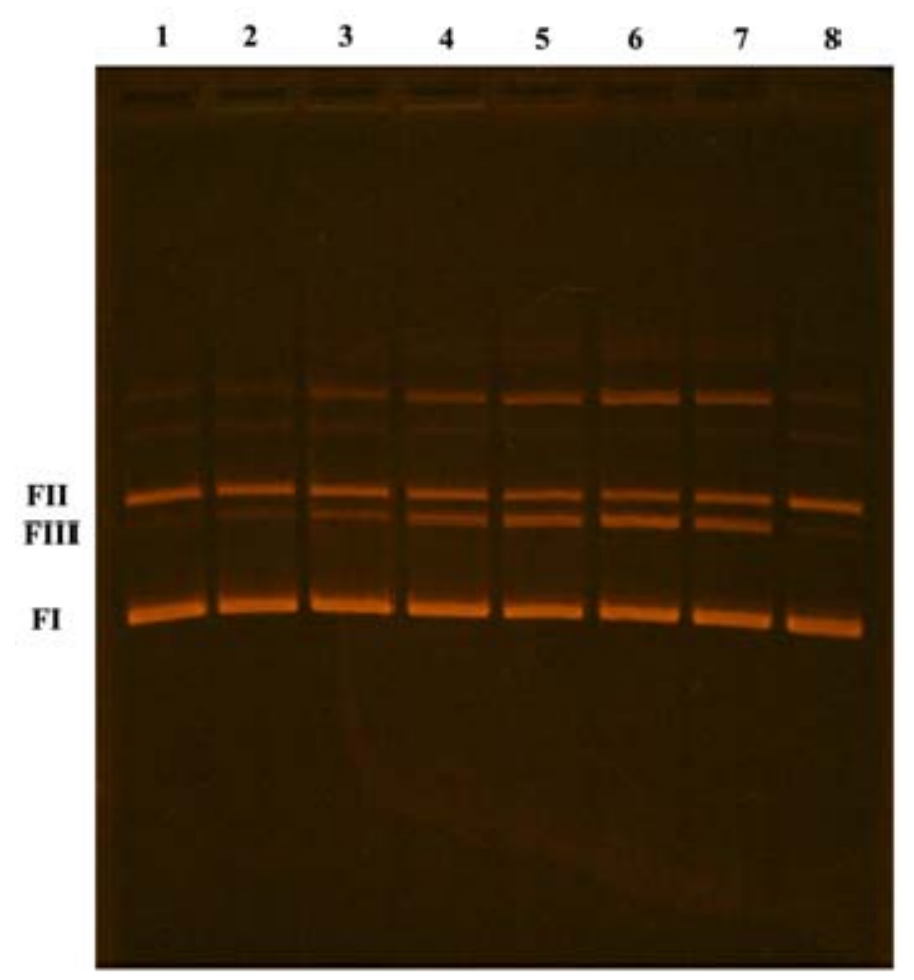

\section{Experimental}

\subsection{General}

2-(Diphenylphosphino)benzaldehyde (97\%), and malonic acid dihydrazide (97\%) were obtained from Sigma-Aldrich (Saint Louis, MO, USA), hydrazine sulfate (99\%) was obtained from Merck (Darmstadt, Germany). All solvents (methanol, acetonitrile) and chemicals used for DNA studies were reagent grade and used without further purification. All buffer solutions for investigations of interactions of compounds with DNA were prepared in deionized sterile water and filtered through $0.2 \mu \mathrm{m}$ filters (Nalgene, Lima Ohio, OH, USA). Ethidium bromide and plasmid pUC18 were purchased from Serva (Heidelberg, Germany). IR spectra were recorded on a Perkin-Elmer FT-IR 
1725X spectrometer using the ATR technique in the region 4,000-400 $\mathrm{cm}^{-1} .{ }^{1} \mathrm{H}-\mathrm{NMR}(200 \mathrm{MHz})$ and ${ }^{13} \mathrm{C}-\mathrm{NMR}(50 \mathrm{MHz})$ for 2 were recorded on a Varian-Gemini 2000 spectrometer in $\mathrm{CDCl}_{3}$ using TMS as internal standard for ${ }^{1} \mathrm{H}$ and ${ }^{13} \mathrm{C} .{ }^{1} \mathrm{H}-\mathrm{NMR}(500 \mathrm{MHz}),{ }^{13} \mathrm{C}-\mathrm{NMR}(125 \mathrm{MHz})$ and 2D NMR spectra for 1 were recorded on a Bruker Avance 500 spectrometer in $\mathrm{CD}_{3} \mathrm{CN}$ using TMS as internal standard for ${ }^{1} \mathrm{H}$ and ${ }^{13} \mathrm{C}$. All spectra were measured at $25{ }^{\circ} \mathrm{C}$. Compound 2 was characterized on the basis of NMR spectroscopy results: 1D $\left({ }^{1} \mathrm{H},{ }^{13} \mathrm{C}\right.$, DEPT). Compound 1 was characterized on the basis of NMR spectroscopy results: $1 \mathrm{D}\left({ }^{1} \mathrm{H},{ }^{13} \mathrm{C}\right.$, DEPT), 2D (COSY, NOESY) as well as $2 \mathrm{D}{ }^{1} \mathrm{H}-{ }^{13} \mathrm{C}$ heteronuclear correlation spectra (HSQC, HMBC). ${ }^{31} \mathrm{P}$ NMR (202 MHz) spectrum for 1 was recorded on a Bruker Avance 500 spectrometer using $85 \%$ phosphoric acid as external standard. Mass spectra were taken on a 6210 TOF LC/MS coupled with an Agilent Technologies 1200 Series HPLC system. A Submarine Mini-gel Electrophoresis Unit (Hoeffer HE 33) with an EPS 300 power supply was used for electrophoresis experiments. The stained gels were illuminated under a Vilber-Lourmat UV transilluminator (Marne-la-Vallée, France) at $312 \mathrm{~nm}$ and photographed with a Panasonic DMC-LZ5 Lumix Digital Camera through a DEEP YELLOW 15 (Tiffen, NY, USA) filter.

\subsection{Synthesis of 5,5,11,11-Tetraphenyl-5,6,11,12-tetrahydro-6,12-biiminodibenzo[b,f][1,5]diphosphocinium Diperchlorate (1) from Malonic Acid Dihydrazide and 2-(Diphenylphosphino)benzaldehyde}

To a solution containing $0.03 \mathrm{~g}(0.23 \mathrm{mmol})$ malonic acid dihydrazide and $0.15 \mathrm{~g}(0.52 \mathrm{mmol})$ 2-(diphenylphosphino)benzaldehyde in methanol $(15 \mathrm{~mL})$ four drops of conc. $\mathrm{HClO}_{4}$ were added and the $\mathrm{pH}$ value was adjusted to $1.5-2$. After stirring the mixture for six hours at $42{ }^{\circ} \mathrm{C}$, a white precipitate formed was filtered off and washed with cold methanol. Single crystals of 1 were obtained by vapor diffusion using acetonitrile, $\mathrm{pH}$ of which was adjusted to 4.6 with $\mathrm{CH}_{3} \mathrm{COOH}$. Yield $14.5 \%$ (29 mg), mp $242{ }^{\circ} \mathrm{C} .{ }^{1} \mathrm{H}-\mathrm{NMR}\left(500 \mathrm{MHz}, \mathrm{CD}_{3} \mathrm{CN}\right) \delta 6.47(2 \mathrm{H}, \mathrm{m}, \mathrm{N} 1 \mathrm{H}), 6.75(2 \mathrm{H}, \mathrm{m}, \mathrm{C} 6 \mathrm{H}), 7.18(6 \mathrm{H}, \mathrm{m}$, $\mathrm{C} 14 \mathrm{H}, \mathrm{C} 24 \mathrm{H}, \mathrm{C} 7 \mathrm{H}), 7.63$ (2H, complex signal, C4H), $7.71(2 \mathrm{H}, \mathrm{m}, \mathrm{C} 5 \mathrm{H}), 7.76(4 \mathrm{H}, \mathrm{m}, \mathrm{C} 22 \mathrm{H}, \mathrm{C} 26 \mathrm{H})$, $7.86(4 \mathrm{H}, \mathrm{m}, \mathrm{C} 12 \mathrm{H}, \mathrm{C} 16 \mathrm{H}), 7.92(10 \mathrm{H}, \mathrm{m}, \mathrm{C} 3 \mathrm{H}, \mathrm{C} 13 \mathrm{H}, \mathrm{C} 15 \mathrm{H}, \mathrm{C} 23 \mathrm{H}, \mathrm{C} 25 \mathrm{H}) ;{ }^{13} \mathrm{C}-\mathrm{NMR}(125 \mathrm{MHz}$, $\left.\mathrm{CD}_{3} \mathrm{CN}\right) \delta 73.5\left(\mathrm{~d},{ }^{l} J=58.9 \mathrm{~Hz}, \mathrm{C} 7\right), 117.8\left(\mathrm{~d},{ }^{2} J=3.12 \mathrm{~Hz}, \mathrm{C} 2\right.$, partly masked by the signal of the solvent), 119.6 (d, $\left.{ }^{1} J=79.0 \mathrm{~Hz}, \mathrm{C} 21\right), 122.4$ (d, $\left.{ }^{1} J=92.9 \mathrm{~Hz}, \mathrm{C} 11\right), 130.2$ (s, C4), 131.4 (m, C22, C26), 131.7 (m, C12, C16, C23, C25), 133.6 (m, C6), 135.2 (s, C5), 135.9 (m, C13, C15), 137.3 (m, C14, C24), 139.7 (m, C3), $142.0(\mathrm{~m}, \mathrm{C} 1) ;{ }^{31} \mathrm{P}-\mathrm{NMR}\left(\mathrm{CD}_{3} \mathrm{CN}\right) \delta 28.21$; IR (vs-very strong, s-strong, m-medium, w-weak): 3644 (w), 2584 (w), 3537 (w), 3298 (s), 2361 (w), 1621 (w), 1584 (w), 1479 (w), 1438 (m), 1096 (vs), 752 (m), 687 (m), 620 (m), 537 (w), 505 (m) cm ${ }^{-1}$; MS (ESI) $\mathrm{m} / z$ Calcd for $\mathrm{C}_{38} \mathrm{H}_{32} \mathrm{~N}_{2} \mathrm{P}_{2}$ 578.2034, found 578.2024. Elemental analysis calcd for $\mathrm{C}_{38} \mathrm{H}_{34} \mathrm{~N}_{2} \mathrm{P}_{2} \mathrm{Cl}_{2} \mathrm{O}_{9}$ : N 3.52\%, C $57.37 \%$, H $4.31 \%$, found: N 3.52\%, C 57.39\%, H 4.35\%.

\subsection{Synthesis of 5,5,11,11-Tetraphenyl-5,6,11,12-tetrahydro-6,12-biiminodibenzo[b,f][1,5]diphosphocinium} Diperchlorate (1) from Malonic Acid Dihydrazide and 2-(Diphenylphosphino)benzaldehyde in the Presence of $\mathrm{Cd}\left(\mathrm{ClO}_{4}\right)_{2} \cdot 6 \mathrm{H}_{2} \mathrm{O}$

$\mathrm{Cd}\left(\mathrm{ClO}_{4}\right)_{2} \cdot 6 \mathrm{H}_{2} \mathrm{O} \quad 0.11 \mathrm{~g}(0.26 \mathrm{mmol})$, malonic acid dihydrazide $0.03 \mathrm{~g}(0.23 \mathrm{mmol})$ and 2-(diphenylphosphino)benzaldehyde $0.15 \mathrm{~g}$, $(0.52 \mathrm{mmol})$ were dissolved in methanol $(15 \mathrm{~mL})$. Four drops of $\mathrm{HClO}_{4}$ were added and the mixture was stirred for six hours at $42{ }^{\circ} \mathrm{C}$. A white precipitate formed was filtered off and washed with cold methanol. Single crystals of 1 were obtained by vapor 
diffusion using acetonitrile, $\mathrm{pH}$ of which was adjusted to 4.6 with $\mathrm{CH}_{3} \mathrm{COOH}$. Yield $16.6 \%$ (33 mg). The white crude precipitate which was obtained from this experimental procedure was purified by column chromatography through silica gel, eluting with a gradient of $10 \%$ to $50 \%$ acetonitrile in toluene to afford (IE)-[2-(diphenylphosphino)benzylidene]hydrazine 2 as a yellow solid. Yield 19.0\% (30 mg), mp $288{ }^{\circ} \mathrm{C} .{ }^{1} \mathrm{H}-\mathrm{NMR}\left(200 \mathrm{MHz}, \mathrm{CDCl}_{3}\right) \delta$ 7.06-7.28 (3H, m, C4H, C11H), 7.31-7.64 (12H, m, C5H, C6H, C9H, C10H, N2H), 8.25-8.31 (1H, m, C3H), $9.22(1 \mathrm{H}, \mathrm{s}, \mathrm{C} 1 \mathrm{H}) ;{ }^{13} \mathrm{C}-\mathrm{NMR}(50 \mathrm{MHz}$, $\left.\mathrm{CDCl}_{3}\right) \delta 159.2\left(\mathrm{~d},{ }^{3} J=6.4 \mathrm{~Hz}, \mathrm{C} 1\right), 137.6\left(\mathrm{~d},{ }^{l} J=6.4 \mathrm{~Hz}, \mathrm{C} 8\right), 133.0\left(\mathrm{~d},{ }^{2} J=11.9 \mathrm{~Hz}, \mathrm{C} 6\right), 132.6$ (s, C7), 131.8 (s, C11), 131.4 (d, $\left.{ }^{2} J=10.0 \mathrm{~Hz}, \mathrm{C} 9\right), 130.5$ (s, C2), 129.6 (d, $\left.{ }^{3} J=12.8 \mathrm{~Hz}, \mathrm{C} 5\right), 128.3$ (s, C3), 128.3 (d, ${ }^{3} J=12.8 \mathrm{~Hz}, \mathrm{C} 10$ ), 127.7 (s, C4); IR (vs-very strong, s-strong, m-medium, w-weak): 3446 (m), 2365 (w), 2254 (w), 1436 (w), 1183 (m), 1109 (m), 1054 (vs), 1028 (vs), 824 (w), 761 (m), $723(\mathrm{w}), 692(\mathrm{w}), 543(\mathrm{~m}) \mathrm{cm}^{-1}$. MS (ESI) $\mathrm{m} / z$ Calcd for $\mathrm{C}_{19} \mathrm{H}_{17} \mathrm{~N}_{2} \mathrm{P}$ 304.11295, found 304.11369. Elemental analysis calcd for $\mathrm{C}_{19} \mathrm{H}_{17} \mathrm{~N}_{2} \mathrm{P}$ : C 74.99\%, N 9.21\%, H 5.63\%, found: C 74.78\%, N 9.13\%, H 5.75\%.

\subsection{Synthesis of 5,5,11,11-Tetraphenyl-5,6,11,12-tetrahydro-6,12-biiminodibenzo[b,f] [1,5]diphosphocinium} Diperchlorate (1) from Malonic Acid Dihydrazide and 2-(Diphenylphosphino)benzaldehyde in the Presence of $\mathrm{Co}\left(\mathrm{ClO}_{4}\right)_{2} \cdot 6 \mathrm{H}_{2} \mathrm{O}$

$\mathrm{Co}\left(\mathrm{ClO}_{4}\right)_{2} \cdot 6 \mathrm{H}_{2} \mathrm{O} \quad 0.09 \mathrm{~g}(0.25 \mathrm{mmol})$, malonic acid dihydrazide $0.03 \mathrm{~g}(0.23 \mathrm{mmol})$ and 2-(diphenylphosphino)benzaldehyde $0.15 \mathrm{~g}(0.52 \mathrm{mmol})$ were dissolved in methanol $(10 \mathrm{~mL})$. Several drops of $\mathrm{HClO}_{4}$ were added and the mixture was stirred for $30 \mathrm{~min}$ at $53{ }^{\circ} \mathrm{C}$. The brownish-red precipitate arose from solution with the white single crystals of $\mathbf{1}$. Yield in traces.

\subsection{Synthesis of 5,5,11,11-Tetraphenyl-5,6,11,12-tetrahydro-6,12-biiminodibenzo[b,f][1,5]diphosphocinium} Diperchlorate (1) from Hydrazine Sulfate and 2-(Diphenylphosphino)Benzaldehyde

To a solution containing $0.03 \mathrm{~g}(0.23 \mathrm{mmol})$ hydrazine sulfate and $0.15 \mathrm{~g}(0.52 \mathrm{mmol})$ 2-(diphenylphosphino)benzaldehyde in methanol $\left(15 \mathrm{~mL}\right.$ ) four drops of conc. $\mathrm{HClO}_{4}$ were added and the $\mathrm{pH}$ value was adjusted to $1.5-2$. After stirring the mixture for three hours at $42{ }^{\circ} \mathrm{C}$, a white precipitate was filtered off and washed with cold methanol. Single crystals of 1 were obtained by vapor diffusion using acetonitrile, $\mathrm{pH}$ of which was adjusted to 4.6 with $\mathrm{CH}_{3} \mathrm{COOH}$. Yield $18.7 \%$ (38 mg).

\subsection{X-ray Single Crystal Measurements}

CCDC 862205 and 862206 contain the supplementary crystallographic data for $\mathbf{1}$ and $\mathbf{1} \times \mathbf{H}_{\mathbf{2}} \mathbf{O}$. These data can be obtained free of charge via http://www.ccdc.cam.ac.uk/conts/retrieving.html, or from the Cambridge Crystallographic Data Centre, 12 Union Road, Cambridge CB2 1EZ, UK; fax: (+44)1223-336-033; or e-mail: deposit@ccdc.cam.ac.uk.

The crystals of $\mathbf{1}$ and $\mathbf{1} \times \mathbf{H}_{\mathbf{2}} \mathbf{O}$ were mounted in a loop containing some amount of perfluoroether as protector and flash cooled on SuperNova kappa-geometry diffractometer to 130(2) K. The temperature of the samples was controlled with an Oxford Instruments Cryosystem cold-nitrogen-gas blower. The diffractometer was equipped with fine-focus $\mathrm{CuK} \alpha$ radiation $(\lambda=1.5405 \AA)$. The intensity data were corrected for absorption effects [21]. The structures were solved by direct methods using SHELXS-86 [22] and refined by least-squares techniques with SHELXL-97 [23]. Anisotropic displacement parameters 
were employed for non-hydrogen atoms. For tertiary and aromatic $\mathrm{CH}$ groups the positions of the hydrogen atoms were calculated at standardized distances of 1.00 and $0.95 \AA$, respectively. The positions of the $\mathrm{NH}$ hydrogens and a hydrogen atom being part of the $\mathrm{C}_{2}$ symmetrical water molecule were determined from the difference Fourier maps but their bond distances were standardized to the values of 0.92 and $0.85 \AA$, respectively. All $\mathrm{H}$-atoms were refined using a riding model with isotropic temperature factors $20 \%$ higher than the isotropic equivalent for the atom to which the $\mathrm{H}$-atom was bonded. At the final stages of the structure refinement it appeared evident that the crystal of 1 contains structural voids each containing the residual electron density of about $0.7 \mathrm{e} \AA^{-3}$. We have assumed that the residual density in the voids represents atmospheric gases and used the SQUEEZE [24] program to account for the presence of this electron density. Hence, the atom list does not contain the gas atoms captured in the crystal. The SQUEEZE program indicated the presence of 8 voids each of the volume ca. $34 \AA^{3}$ containing 4 electrons. The presence of voids would explain lower density of 1 compared to its hydrated crystal form (Table S1). Siemens [25] computer graphics program was used to prepare drawings. The relevant crystal data collection and refinement parameters are listed in Table S1 and selected bond distances and angles are reported in Table S2 of the Supplementary Material.

\subsection{The Brine Shrimp Test}

A teaspoon of lyophilized eggs of the brine shrimp Artemia salina was added to $0.5 \mathrm{~L}$ of the artificial sea water containing several drops of yeast suspension $(3 \mathrm{mg}$ of dry yeast in $5 \mathrm{~mL}$ distilled water), and air was passed through the suspension thermostated at $18-20^{\circ} \mathrm{C}$, under illumination for $48 \mathrm{~h}$. Hatched nauplii were used in further experiments.

The tested substances were dissolved in appropriate solvents ( $\mathbf{1}$ in acetonitrile, $\mathbf{2}$ in chloroform) and then in various amounts applied to paper discs $2 \mathrm{~cm}$ in diameter. Paper discs were placed on the bottom of the glass vial into which was added $5 \mathrm{~mL}$ of artificial sea water, 1-2 drops of yeast suspension, and about 15-20 hatched nauplii.

The vials were left at room temperature under illumination for $24 \mathrm{~h}$, and afterwards live and dead nauplii were counted. $\mathrm{LC}_{50}$ was defined as the concentration of substances that causes death of $50 \%$ nauplii.

\subsection{DNA Cleavage Experiment}

Plasmid pUC18 was prepared by transformation of a clone from Escherichia coli RR1 (pUC18, 2686 bp, purchased from Sigma, Saint Louis, MO, USA) into electrocompetent E. coli DH5 $\alpha$ strain cells according to the protocol for growing $E$. coli culture overnight in $\mathrm{LB}$ medium at $37{ }^{\circ} \mathrm{C}$ by electroporation with the "Gene Pulser" (Bio-Rad, USA) [26]. The plasmid DNA from E. coli clones was isolated by modified method of alkali lysis [27] and purified with the "JetStar" kit (Genomed, Aventura, USA) using anion-exchange column. After final washing step with ice-cold $70 \%$ ethanol, DNA pellet was air-dried and finally resuspended in $150 \mu \mathrm{L}$ sterile $\mathrm{H}_{2} \mathrm{O}$ and stored at $-20{ }^{\circ} \mathrm{C}$. The concentration of plasmid DNA (213 ng/ $\mu \mathrm{L}$ of pUC18) was determined by measuring the absorbance of the DNA-containing solution at $260 \mathrm{~nm}$. One optical unit corresponds to $50 \mu \mathrm{g} / \mathrm{mL}$ of double stranded DNA.

Stock solution ( $5 \mathrm{mM}$ ) of 1 was prepared in acetonitrile. Plasmid DNA was incubated for 4 min at $95{ }^{\circ} \mathrm{C}$, followed by incubation at $4{ }^{\circ} \mathrm{C}$ for the next $20 \mathrm{~min}$. Then $213 \mathrm{ng}$ of pUC18 in a $20 \mu \mathrm{L}$ reaction 
mixture in $20 \mathrm{mM}$ Tris $20 \mathrm{mM} \mathrm{NaCl}$ buffer $\mathrm{pH}$ 7.92, were incubated with different concentrations ( $0.25 \mathrm{mM}, 0.50 \mathrm{mM}, 0.75 \mathrm{mM}, 1.00 \mathrm{mM}, 1.25 \mathrm{mM}$ and $1.5 \mathrm{mM})$ of 1 at $37{ }^{\circ} \mathrm{C}$, for $2 \mathrm{~h}$. The reaction mixtures were vortexed from time to time. The reaction was terminated by short centrifugation at $10,000 \mathrm{rpm}$ and adding $7 \mu \mathrm{L}$ of loading buffer $(0.25 \%$ bromophenol blue, $0.25 \%$ xylene cyanol $\mathrm{FF}$ and $30 \%$ glycerol in TAE buffer, $\mathrm{pH} 8.24$ (40 mM Tris-acetate, $1 \mathrm{mM}$ EDTA). The samples were subjected to electrophoresis on $1 \%$ agarose gel (GE Healthcare Life sciences, Uppsala, Sweden) prepared in TAE buffer $\mathrm{pH} 8.24$. The electrophoresis was performed at a constant voltage $(80 \mathrm{~V})$ for about $1.5 \mathrm{~h}$ (until bromophenol blue had passed through $75 \%$ of the gel). After electrophoresis, the gel was stained for 30 min by soaking it in an aqueous ethidium bromide solution $(0.5 \mu \mathrm{g} / \mathrm{mL})$, and after that was visualized under UV light.

\section{Conclusions}

Reported here is the preparation of a racemic diphosphonium compound that contains two nearly perpendicular benzene rings fused with an eight-membered ring and a hydrazine bridge. This compound, for which a variety of derivatives with potential biological activity could be synthesized, might be of use due to the fact that chiral molecules that lock two aromatic rings in almost perpendicular planes are of special interest as DNA probes.

\section{Supplementary Materials}

Crystal data (Figure S1 and Table S1), selected geometrical parameters (Table S2), hydrogen-bond parameters (Table S3, Figure S2 and S3) and spectral data (Figure S4-S17). Detailed information can be accessed at: http://www.mdpi.com/1420-3049/17/3/2567/s1.

\section{Acknowledgment}

This work was supported by Grant No.172055 from the Ministry of Education and Science of the Republic of Serbia.

\section{References and Notes}

1. Anđelković, K.; Sladić, D.; Bacchi, A.; Pelizzi, G.; Filipović, N.; Rajković, M. Complexes of iron(II), iron(III) and zinc(II) with condensation derivatives of 2-acetylpyridine and oxalic or malonic dihydrazide. Crystal structure of tris[(1-(2-pyridyl)ethylidene)hydrazine]iron(II) perchlorate. Transition Met. Chem. 2005, 30, 243-250.

2. Filipović, N.R.; Bacchi, A.; Lazić, M.; Pelizzi, G.; Radulović, S.; Sladić, D.M.; Todorović, T.R.; Anđelković, K.K. Synthesis, structure and cytotoxic activity evaluation of a dinuclear complex of $\mathrm{Cd}(\mathrm{II})$ with N',N'2-bis[(1E)-1-(2-pyridyl)ethylidene]propanedihydrazide. Inorg. Chem. Commun. 2008, 11, 47-50.

3. Vujčić, M.; Lazić, M.; Milenković, M.; Sladić, D.; Radulović, S.; Filipović, N.; Anđelković, K. A comparative study of DNA binding and cell cycle phase perturbation by the dinuclear complex of $\mathrm{Cd}(\mathrm{II})$ with the condensation product of 2-acetylpyridine and malonic acid dihydrazide N',N'2. bis[(1E)-1-(2-pyridyl)ethylidene]propanedihydrazide. J. Biochem. Mol. Toxicol. 2011, 25, 175-182. 
4. Eshkourfu, R.; Čobeljić, B.; Vujčić, M.; Turel, I.; Pevec, A.; Sepčić, K.; Zec, M.; Radulović, S.; Srdić-Radić, T.; Mitić, D.; Anđelković, K.; Sladić, D. Synthesis, characterization, cytotoxic activity and DNA binding properties of the novel dinuclear cobalt(III) complex with the condensation product of 2-acetylpyridine and malonic acid dihydrazide. J. Inorg. Biochem. 2011, 105, 1196-1203.

5. Todorović, T.R.; Rychlewska, U.; Warżajtis, B.; Radanović, D.D.; Filipović, N.R.; Pajić, I.A.; Sladić, D.M.; Anđelković, K.K. Synthesis, characterization and antimicrobial activity of Ni(II) and $\mathrm{Zn}$ (II) complexes with $\mathrm{N}^{\prime}, \mathrm{N}^{\prime 2}$-bis[(1E)-1-(2-pyridyl)ethylidene]propanedihydrazide. Crystal structures of two highly solvated bimetallic complexes of Ni(II). Polyhedron 2009, 28, 2397-2402.

6. Bayly, S.R.; Cowley, A.R.; Dilworth, J.R.; Ward, C.V. Ruthenium complexes with tridentate PNX (X = O, S) donor ligands. Dalton Trans. 2008, 2190-2198.

7. Liu, P.N.; Su, F.H.; Wen, T.B.; Sung, H.H.-Y.; Williams, I.D.; Jia, G. Selective and Efficient Cycloisomerization of Alkynols Catalyzed by a New Ruthenium Complex with a Tetradentate Nitrogen-Phosphorus Mixed Ligand. Chem. Eur. J. 2010, 16, 7889-7897.

8. Thibault, M.; Lucier, B.E.G.; Schurko, R.W.; Fontaine, F. Synthesis and solid-state characterization of platinum complexes with hexadentate amino- and iminophosphine ligands. Dalton Trans. 2009, 7701-7716.

9. Campo, O.; Carbayo, A.; Cuevas, J.V.; García-Herbosa, G.; Muñoz, A. Isomeric Preference in Complexes of Palladium(II) with Chelating P,N-Donor Ligands. Eur. J. Inorg. Chem. 2009, 2009, 2254-2260.

10. Sui-Seng, C.; Haque, F.N.; Hadzovic, A.; Pütz, A.; Reuss, V.; Meyer, N.; Lough, A.J.; Zimmer-De Iuliis, M.; Morris, R.H. Synthesis and Characterization of Iron(II) Complexes with Tetradentate Diiminodiphosphine or Diaminodiphosphine Ligands as Precatalysts for the Hydrogenation of Acetophenone. Inorg. Chem. 2009, 48, 735-743.

11. Williams, D.B.G.; Pretorius, M. Synthesis and evaluation of phosphine-N ligands in transition metal-catalysed C-C bond forming reactions. J. Mol. Catal. A: Chem. 2008, 284, 77-84.

12. Radulović, V.; Bacchi, A.; Pelizzi, G.; Sladić, D.; Brčeski, I.; Anđelković, K. Synthesis, Structure, and Antimicrobial Activity of Complexes of $\mathrm{Pt}(\mathrm{II}), \mathrm{Pd}(\mathrm{II})$, and $\mathrm{Ni}(\mathrm{II})$ with the Condensation Product of 2-(Diphenylphosphino)benzaldehyde and Semioxamazide. Monatsh. Chem. 2006, 137, 681-691.

13. Malešević, N.; Srdić, T.; Radulović, S.; Sladić, D.; Radulović, V.; Brčeski, I.; Anđelković, K. Synthesis and characterization of a novel $\mathrm{Pd}(\mathrm{II})$ complex with the condensation product of 2-(diphenylphosphino) benzaldehyde and ethyl hydrazinoacetate. Cytotoxic activity of the synthesized complex and related Pd(II) and Pt(II) complexes. J. Inorg. Biochem. 2006, 100, 1811-1818.

14. Wilson, A.J.C., Ed. International Tables for Crystallography; Kluwer Academic Publishers: Dordrecht, The Netherlands, 1995; Volume C, pp. 796-811.

15. Dalpozzo, R.; Bartoli, G.; Sambri, L.; Melchiorre, P. Perchloric Acid and Its Salts: Very Powerful Catalysts in Organic Chemistry. Chem. Rev. 2010, 110, 3501-3551.

16. Ben-Aroya, B.B.; Portnoy, M. Addition of borane-protected secondary phosphines to imines. A route to protected mono- $N$-substituted- $\alpha$-aminophosphines. Tetrahedron Lett. 2000, 41, 6143-6147. 
17. Bhutani, H.; Singh, S.; Jindal, K.C.; Chakraboti, A.K. Mechanistic explanation to the catalysis by pyrazinamide and ethambutol of reaction between rifampicin and isoniazid in anti TB FDCs. J. Pharm. Biomed. Anal. 2005, 39, 892-899.

18. Maerkl, G. Innermolekulare C-Alkylierung von Phosphin-methylenen zu cyclischen Phosphoniumsalzen und Phosphor-Yliden. Z. Naturforsch. 1963, 18b, 84-85.

19. Meyer, B.N.; Ferrigni, N.R.; Putnam, J.E.; Jacobsen, L.B.; Nichols, D.E.; McLaughlin, J.L. Brine shrimp: A convenient bioassay for active plant constituents. Planta Med. 1982, 45, 31-34.

20. Anderson, J.E.; Goetz, C.M.; McLaughlin, J.L.; Suffness, M. A blind comparison of simple benchtop bioassays and human tumour cell cytotoxicities as antitumor prescreens. Phytochem. Anal. 1991, 2, 107-111.

21. Oxford Diffraction CrysAlis CCD and CrysAlisRED including ABSPACK, Version 1.171 Oxford Diffraction, Oxfordshire, England, 2000.

22. Sheldrick, G.M. Phase annealing in SHELX-90: Direct methods for larger structures. Acta Crystallogr. Sect. A 1990, 46, 467-473.

23. Sheldrick, G.M. A short history of SHELX. Acta Crystallogr. Sect. A 2008, 64, 112-122.

24. Spek, A.L. PLATON, A Multipurpose Crystallographic Tool; Utrecht University: Utrecht, The Netherlands, 2010.

25. XP, Siemens Analytical X-ray Instruments Inc. Madison, Wisconsin, USA, 1990.

26. Dower, W.J.; Miller, J.F.; Ragsdale, C.W. High efficiency transformation of E. coli by high voltage electroporation. Nucleic Acids Res. 1988, 16, 6127-6145.

27. Birnboim, H.C.; Doly, J. A rapid alkaline extraction procedure for screening recombinant plasmid DNA. Nucleic Acids Res. 1979, 7, 1513-1523.

Sample Availability: Sample of the compound $\mathbf{1}$ is available from the authors.

(C) 2012 by the authors; licensee MDPI, Basel, Switzerland. This article is an open access article distributed under the terms and conditions of the Creative Commons Attribution license (http://creativecommons.org/licenses/by/3.0/). 